\title{
MEDIALNY OBRAZ POLITYKA W TYGODNIKU OPINII "NEWSWEEK" W PREZYDENCKIEJ KAMPANII WYBORCZEJ Z 2015 ROKU W POLSCE
}

\author{
MEDIA VIEW OF POLITICIAN IN NEWSWEEK MAGAZINE \\ BASED ON PRESIDENTIAL CAMPAIGN IN 2015 IN POLAND
}

Katarzyna Wierak* 미

\begin{abstract}
- ABSTRAKT
Medialny obraz polityka to, w dobie dzisiejszych kampanii wyborczych, istotne zagadnienie warte dokładnej analizy. Prezentowane w mediach wizerunki polityczne są często przedstawiane w sposób stronniczy, nierzadko subiektywny, powodując tym samym przekłamanie rzeczywistości. W artykule dokonano analizy tekstów publicystycznych zamieszczonych w tygodniku opinii „Newsweek” w czasie trwania kampanii prezydenckiej w 2015 r. Celem badania było ukazanie prezentowanych medialnych obrazów polityków oraz wskazanie na ich charakter, przy założeniu stronniczości przekazu medialnego.
\end{abstract}

Słowa kluczowe: medialny obraz świata; wizerunek polityczny; kampania wyborcza; publicystyka
Politician media image is a very significant issue worth to analyze, especially when it comes to election campaign period. In mass media we can observe partial political images, more often subjective, which is responsible for mangling the reality. The paper contains an analysis of journalistic articles from weekly newspaper "Newsweek" during the presidential campaign in 2015. The main goal of this paper is to indicate media images of the candidates and show their main attributes, remembering of partial context of the media news.

Keywords: media view of reality; political image; election campaign; journalistic writing

* Uniwersytet Marii Curie-Skłodowskiej w Lublinie, Wydział Politologii i Dziennikarstwa. 


\section{WSTĘP}

Celem niniejszego artykułu jest analiza medialnego obrazu polityka w polskiej publicystyce, w czasie trwania kampanii prezydenckiej w 2015 r. Za materiał badawczy posłużył tygodnik „Newsweek”, uznany za najbardziej opiniotwórcze medium prasowe w $2015 \mathrm{r}^{1}$. Przyjęta cezura czasowa to okres od 26 marca $^{2}$, kiedy mijał termin zgłaszania kandydatów na Prezydenta Rzeczypospolitej Polskiej ${ }^{3}$, do 24 maja, czyli przeprowadzenia drugiej tury wyborów prezydenckich. Pod uwagę wzięto dwóch głównych kandydatów: Andrzeja Dudę oraz Bronisława Komorowskiego ${ }^{4}$.

Przyjętą metodą badawczą jest analiza zawartości, tu: analiza zawartości prasy w aspekcie ilościowym i jakościowym. Za jednostkę badawczą przyjęto tekst, który w swojej zawartości dotyczył tematyki kampanii prezydenckiej. Ogółem przebadano 8 numerów (które ukazały się w okresie od 30 marca do 18 maja), w czym 35 tekstów, które dotyczyły bądź w których wspomniano o kampanii wyborczej i jej czołowych kandydatach.

W ramach analizy zawartości tekstu przyjęto klucz kategoryzacyjny, wzięto w nim pod uwagę: program wyborczy obu kandydatów, wystąpienia medialne, spotkania $\mathrm{z}$ wyborcami, wpadki wizerunkowe oraz relacje pomiędzy oboma kandydatami i partiami politycznymi, z których się wywodzą. Przyjęto chronologiczny porządek pracy. Postawiono również następujące pytania badawcze. Czy dochodzi do stronniczości mediów i faworyzowania wybranych kandydatów? Czy w tekstach publicystycznych dochodzi do zniekształcenia rzeczywistości poprzez subiektywny opis wydarzeń i ich interpretację? Czy media podają informacje wybiórczo i czy wszystkie informacje zostają przekazywane przez konkretne media?

1 Opiniotwórczość danego medium określana jest poprzez ilość cytowań przez inne media. W przypadku prasy, spośród tygodników, największą częstotliwość cytowań w pierwszym półroczu 2015 roku odnotował „Newsweek”. Szczegółowy raport „Najbardziej opiniotwórcze media” został przygotowany przez Instytut Monitorowania Mediów (Instytut Monitorowania Mediów, 2015).

2 Do dnia 26 marca 2015 roku do godziny 24:00, należało zgłosić Państwowej Komisji Wyborczej kandydatów na Prezydenta Rzeczypospolitej Polskiej w celu zarejestrowania (Państwowa Komisja Wyborcza, 2015).

3 W celu zarejestrowania kandydata na Prezydenta RP formalnym obowiązkiem jest zebranie co najmniej 100 tys. podpisów popierających danego kandydata (Infor.pl Prawo, 2015).

4 Poza Andrzejem Dudą i Bronisławem Komorowskim zarejestrowanych zostało 9 innych kandydatów: Grzegorz Braun, Adam Jarubas, Janusz Korwin-Mikke, Marian Kowalski, Paweł Kukiz, Magdalena Ogórek, Janusz Palikot, Paweł Tanajno oraz Jacek Wilk (Państwowa Komisja Wyborcza, 2015). 


\section{MEDIALNY OBRAZ ŚWIATA}

Za jednego z pierwszych badaczy, który dostrzegł, że media tworzą w umysłach odbiorców zniekształcone obrazy świata, uważa się Waltera Lippmanna (1921, za: Hofman, Kępa-Figura, 2015, s. 13). Określił on ów obraz jako stereotyp, czyli zjawisko, które najczęściej powstaje w wyniku doświadczenia jednostki. Doświadczenie to jednak zostało ukształtowane w wyniku pewnego przekazu i z niego zapożyczone (Stephan, Stephan, 2003, s. 15-16). Można tu również mówić o przekazie medialnym. Należy jednak pamiętać, że rozumień medialnego obrazu świata czy obrazu medialnego jest znacznie więcej, a tym samym pojawia się wiele jego definicji w literaturze. Jedną z nich prezentuje Michael Fleischer (2000), który uważa, że zarówno konstrukcja czy też zapośredniczona rzeczywistość oraz manipulacja dokonywana w mediach zawsze była i jest popularnym obszarem zainteresowań badawczych w publicystyce czy badaniach prasoznawczych. Sam medialny obraz świata traktuje jako składową kulturowego obrazu świata, przytaczając także inne jego komponenty ${ }^{5}$, wnioskując jednocześnie, że kompletny obraz świata tworzy się dopiero po połączeniu z językowym obrazem świata ${ }^{6}$. Tym samym można wnioskować, że kulturowy obraz świata nadbudowuje się na językowy obraz świata (Hofman, Kępa-Figura, 2015, s. 14), a sam obraz świata wykazuje oddziaływanie pierwszej rzeczywistości i produkowanie przez drugą rzeczywistość komponentów sterujących, które mają ma celu organizowanie i sterowanie komunikacją w danym systemie kultury (Dąbrowska, Anusiewicz, 2000, s. 65-66).

M. Fleischer w swoich badaniach zwracał również uwagę na zjawisko manipulacji, co jest istotne w kontekście przedmiotu badań niniejszego artykułu. Sięgając do teorii konstruktywizmu, M. Fleischer dowodzi, że z tej perspektywy problem nie istnieje, ponieważ manipulacja jest swoistego rodzaju nieodzownym elementem. Tym samym, zdaniem M. Fleischera, należy rozumieć, że wszyscy manipulujemy i jesteśmy manipulowani (Fleischer, 2005, s. 10).

Medialny obraz świata określany jest również jako medialny obraz rzeczywistości. Tak określa to pojęcie Jan Szmyd (2012), wskazując na medialny obraz świata jako całościowy przekaz medialny, który układa się w pewnego rodzaju

Zdaniem M. Fleischnera obok komponentu medialnego, w skład kulturowego obrazu świata wchodzą jeszcze komponent naukowy, artystyczny, religijny, polityczny oraz ekonomiczny (Dąbrowska, Anusiewicz, 2000, s. 65-66).

6 O Językowym Obrazie Świata (JOŚ) w dalszej części rozważań. 
obraz prezentowanej rzeczywistości. Ów przekaz, jak zauważa badacz, składa się z różnorakich treści informacyjnych, znakowo symbolicznych, audiowizualnych, w formie językowej, obrazowej, dźwiękowej, przekazywany poprzez system różnorodnych komunikatów (Pokorna-Ignatowicz, 2012, s. 13-14). Powtarza za amerykańskimi badaczami: Byronem Reevesem i Clifordem Nassem (2000), że wszyscy ludzie, pochodzący z różnych kultur, będący także w różnym wieku, o różnym poziomie wykształcenia czy mający zróżnicowane doświadczenia $\mathrm{z}$ technologią, $\mathrm{w}$ dalszym ciągu podobnie reagują na media (Pokorna-Ignatowicz, 2012, s. 15).

Innym rozumieniem medialnego obrazu świata jest to prezentowane przez Danutę Kępę-Figurę i Pawła Nowaka. Dwójka badaczy uważa, że medialny obraz świata ma być jedynie reinterpretacją językowego obrazu świata ${ }^{7}$. Takie przekonanie bierze się stąd, że medialny obraz świata jest swoistego rodzaju przetworzeniem językowego obrazu (Kępa-Figura, Nowak, 2006, s. 59).

Według Agnieszki Ogonowskiej (2003, s. 18) obraz medialny przestał odwzorowywać rzeczywistość, a zaczął tworzyć obrazy rzeczywistości, których związek z realnym światem przestał mieć na dobrą sprawę znaczenie. Największe ryzyko stanowi tutaj fakt, że zdaniem badaczki odbiorca niekoniecznie dostrzega różnicę pomiędzy światem realnym a medialnym. Sytuacja ta dotyczy również wyborów politycznych, kiedy to decyzje o udzieleniu legitymacji władzy podejmowane są właśnie na podstawie medialnych obrazów polityki i polityków (Ogonowska, 2003, s. 18).

7 W literaturze istnieje wiele definicji językowego obrazu świata, jedną z popularniejszych jest definicja prezentowana przez Renatę Grzegorczykową, która uznaje językowy obraz świata za strukturę pojęciową utrwaloną w systemie danego języka, to znaczy jego właściwościach gramatycznych i leksykalnych, która realizuje się za pomocą tekstów, tak jak wszystko w języku (Grzegorczykowa, 1990, s. 43).

Wcześniej definicję językowego obrazu świata zaproponowali Jerzy Bartmiński i Ryszard Tokarski, którzy uznali to pojęcie za pewien zespół sądów mniej lub bardziej utrwalonych w języku, które zawarte są w znaczeniach wyrazów lub są przez te znaczenia implikowane. Ów zespół sądów orzeka o cechach i sposobach istnienia obiektów świata pozajęzykowego (Bartmiński, Tokarski,1986, (red.). Dobrzyńska, Janus, 1986, s. 72). 


\section{WIZERUNEK POLITYCZNY}

Drugim, istotnym dla artykułu zagadnieniem jest wizerunek polityczny. Co interesujące, za prekursora tego pojęcia uważa się Waltera Lippmanna, badacza, który nieco wcześniej był tu przytaczany w kontekście medialnego obrazu jako stereotypu. W kontekście wizerunku W. Lippmann jako pierwszy zestawił ze sobą tworzenie się opinii publicznej z uproszczonymi wyobrażeniami odbiorcy na temat spraw publicznych (Jeziński, 2004, s. 79). W literaturze przedmiotu definicji wizerunku jest wiele. Dlatego stworzenie jednej, idealnej definicji jest trudne. Bardzo interesujące i adekwatne jest podejście Mariusza Kolczyńskiego, który proponuje trzy rodzaje definicji wizerunku (Kolczyński, 2008, s. 276). Po pierwsze definicje ogólne - gdzie wizerunkiem będzie zbiór przekonań, koncepcji czy wrażeń, jakie odbiorca żywi wobec podmiotu politycznego. Drugi rodzaj to definicje, które mają podkreślać znaczenie indywidualnych procesów poznawczych oraz symboliczny wymiar wizerunku. Trzecią kategorię zaś stanowią definicje, które mają skupiać się na przesłaniu oraz zawartości wizerunku. Tu w grę wchodzą zarówno osobiste i polityczne atrybuty kandydata, jak również jego koncepcje programowe (Kolczyński, 2008, za: Maguś, 2014, s. 20).

Przy definiowaniu pojęcia wizerunku politycznego należy pamiętać, że jest on pochodną autoprezentacji. Jest to zasadne spostrzeżenie, ponieważ występowanie wielorakich typów wizerunków politycznych ${ }^{8}$, a więc tym samym odgrywanie przez polityków różnych ról podczas kampanii wyborczej, ma wszakże oddziaływać na wyborcę (Dobek-Ostrowska 2005, s. 115). Kolejną kwestią, o której należy pamiętać, jest to, że wizerunek polityczny, podobnie zresztą jak sam polityk, często bywa traktowany jak produkt. Produkt, który należy odpowiednio wypromować i sprzedać z sukcesem (Kasińska-Metryka, 2006, s. 157).

Zdaniem W. Cwaliny (2010) wizerunek niekoniecznie powinien opierać się na cechach rzeczywistych kandydata. Te bowiem mają mieć określone znaczenie dla odbiorcy, który przecież nie wie, czy są one prawdziwe. Ideą wizerunku jest zapewnienie jego odbiorcy emocjonalnego odbioru polityka, jednocześnie nie tracąc przy tym istoty jego wizerunku (Cwalina, 2010, s. 61). Warto również wspomnieć, że wizerunek polityczny może zostać wykreowany jedynie na potrzebę chwili, czyli tutaj kampanii wyborczej. Wówczas określa się go mianem

8 Klasycznego i często używanego w literaturze podziału wizerunku politycznego na określone typy dokonał Marek Jeziński, (zob. szerzej Jeziński, 2005, (red.). Dobek-Ostrowska, 2005, s. 115). 
wizerunku sztucznego, nie zaś wiarygodnego, którego będzie przeciwieństwem (Zaręba, 2011, s. 17-18).

\section{ANALIZA - ANDRZEJ DUDA}

W kontekście postulatów wyborczych A. Duda określany był w sposób negatywny jako oszust i cyniczny kandydat (Lis, 2015a, s. 5), „opowiadający straszne bzdury” (Zob.: Lis, 2015b, s. 2; Lis, 2015a, s. 5), który światopoglądowo, obyczajowo czy gospodarczo i politycznie jest uzależniony od takich postaci, jak Tadeusz Rydzyk czy J. Kaczyński (Lis, 2015b, s. 2; Lis, 2015a, s. 5). W kwestii Smoleńska zaś jest „Zausznikiem Macierewicza” (Lis, 2015a, s. 5). Tomasz Lis w jednym ze swoich „wstępniaków” dla „Newsweeka” określił go jako kandydata „kopiuj i wklej” (Lis, 2015b, s. 2). W kwestiach programowych. A. Duda określany był jako kandydat, który „wychodzi z tezą obrażającą rozsądek odbiorców” (Kalukin, 2015a, s. 19) i wspólnie z J. Kaczyńskim chce „uśpić rozum, który każe nam się integrować z Zachodem” (Michalski, 2015, s. 22), budzi z kolei „upiory zależności od Wschodu" (Michalski, 2015, s. 22).

W odniesieniu do założeń programowych poruszano kwestię m.in. sztucznego zapłodnienia. „Newsweek” pisał, że A. Duda chce „wsadzać do więzienia za in vitro" (Krzymowski, 2015a, s. 31; Lis, 2015c, s. 2; Michalski, 2015, s. 22). Dodatkowo, że popiera tylko taki sposób sztucznego zapłodnienia, który nota bene nie daje żadnej szansy na dziecko (Lis, 2015d, s. 2). W negatywnym tonie pisano również o poruszanej przez przyszłego prezydenta kwestii wejścia do strefy euro (Lis, 2015d, s. 2; Michalski, 2015, s. 22; Krzymowski, 2015a, s. 31) oraz obietnicy obniżenia wieku emerytalnego (Lis, 2015a, s. 5; Kalukin, 2015b, s. 26). Pojawiał się również zarzut, że A. Duda bardzo wiele obiecuje, co może prowadzić do katastrofy gospodarczej, recesji i upadku bankowości ${ }^{9}$. Podkreślano, że obietnic tych jest tak wiele, że kandydat traci inwencję twórczą w wymyślaniu kolejnych (Kalukin, 2015b, s. 26) i przestaje mieć pojęcie, co obiecuje wyborcom (Lis, 2015a, s. 5).

Poza kwestiami programowymi w tekstach publicystycznych poruszano tematykę wizerunku. Określano A. Dudę jako kandydata, który nie próbuje budować pozytywnego wizerunku i jest politykiem, o którym niewiele wiadomo,

9 W tym przypadku chodziło o obietnicę przewalutowania frankowych kredytów po kursie, jaki obowiązywał w dniu ich zaciągnięcia (Zob. szerzej: Lis, 2015a, s. 5). 
ponieważ trudno określić jego poglądy, osobowy rys, wyznawane idee. Pisano, że jest równie nieokreślony, jak na początku ogłaszania swojej kampanii (Kalukin, 2015b, s. 26). Przy okazji afery ze SKOK-ami (Zob. szerzej: Kalukin, 2015c, s. 41) kandydata PiS określano jako tego, który w pojedynkę ukradł trzy miliardy złotych z kieszeni Polaków (Meller, 2015a, s. 44), mówiono, że jest lobbystą SKOK-ów (Lis, 2015d, s. 2), a przy tym nie posiada żadnego kręgosłupa moralnego (Lis, 2015c, s. 2). A. Duda był także określany jako bezideowy kłamca, zwykły karierowicz i oportunista, który udaje uczciwego (Lis, 2015c, s. 2; Hołdys, 2015, s. 53).

Ważną kwestią było podkreślanie jego zależności od partii PiS i prezesa J. Kaczyńskiego (Krzymowski, 2015b, s. 22). Pisano o kandydacie PiS jako polityku, który nie może pozwolić sobie na zrozumiałe komunikowanie z wyborcami, ponieważ jest ograniczony tradycyjnymi hasłami PiS-u (Kalukin, 2015b, s. 28). Znowu pojawiały się określenia, że jest kombinacją J. Kaczyńskiego, A. Macierewicza i T. Rydzyka (Lis, 2015e, s. 3). Jak pisał T. Lis, kandydat PiS przez pół roku swojej kampanii nie powiedział ani jednego zdania, które mogłoby nie spodobać się prezesowi partii (Lis, 2015d, s. 2). Pisano o nim jako lojalnym wobec prezesa (Krzymowski, 2015b, s. 20). A. Duda był przez publicystów określany jako „rozmazany, plastikowy, ślizgający się po powierzchni” (Kalukin, 2015b, s. 28), „trochę populistyczny [...], poukładany katolik, technokrata" (Kalukin, 2015b, s. 28).

Po ogłoszeniu wyników po pierwszej turze wyborów ${ }^{10}$ pisano o A. Dudzie, że jeszcze nigdy w historii Polski „tak dużej liczby głosów nie zdobył człowiek całkowicie pozbawiony osiągnięć, charyzmy, samodzielności i charakteru" (Lis, 2015d, s. 2). Zarzucano mu brak umiejętności przywódczych i bycie instrumentem w rękach prezesa PiS (Pawlicka, 2015a, s. 18). Sugerowano, że A. Duda gra ze swoimi wyborcami w „pomidora”, jedynie kluczowe słowo zastąpił innym - „nauczaniem Jana Pawła II” (Meller, 2015b, s. 20) i jeśli wygra, będzie zmianą na gorsze (Lis, 2015a, s. 4), a Polska zyska prezydenta, który „jest panem nikt” (Pawlicka, 2015b, s. 22).

Kolejny analizowany element to wystąpienia medialne kandydata. Wzmianek o tej kwestii było niewiele. Wspomniano jedynie o pierwszej debacie wyborczej w kontekście przewidywania pozytywnych komentarzy ze strony partii na temat tego, jak dobrze wypadł w niej A. Duda (Lis, 2015d, s. 3).

10 Andrzej Duda wygrał ją o jeden punkt procentowy z Bronisławem Komorowskim. Tym samym obaj kandydaci dostali się do drugiej tury wyborów (Zob. szerzej: Państwowa Komisja Wyborcza, 2015). 
Podczas analizy nie doszukano się komentarzy odnośnie samych spotkań z wyborcami. Wyniknęła natomiast nowa kategoria, którą były komentarze publicystów określające swoistego rodzaju zależności łączące kandydatów z partiami, z których się wywodzą. W przypadku A. Dudy zwracano uwagę, że w jego kampanii i spotach wyborczych „czuć rękę Jacka Kurskiego”, który wciska ludowi „odrażającą ciemnotę” (Kalukin, 2015a, s. 19). Z kolei politycy PiS ciągle próbują przypominać wyborcom o zdjęciu B. Komorowskiego z „aferzystą z WSI"11 (Kalunkin, 2015c, s. 41).

\section{ANALIZA - BRONISŁAW KOMOROWSKI}

Rozpoczynając analizę obrazu B. Komorowskiego, należy zaznaczyć, że komentarzy na temat byłego prezydenta było nieco mniej. W kwestiach programowych zaznaczano, że kampania B. Komorowskiego rozkręca się powoli (Kalukin, 2015c, s. 40), jest dość niemrawa, mimo tego, że jego kontrkandydat sam daje mu amunicję do ręki (Lis, 2015c, s. 2), a przez to PO miała być tym samym „skazana na władzę" (Kalukin, 2015e, s. 6). Komentowano kampanię B. Komorowskiego jako ubogą w kwestiach refleksji i diagnoz. Jednak na tle kampanii A. Dudy określano ją jako oazę kultury politycznej (Kalukin, 2015a, s. 19). Nietrafionym określano również podział Polski na „racjonalną” i „radykalną”, o którym B. Komorowski mówił w programie (Kalukin, 2015a, s. 19). B. Komorowski deklarował reprezentowanie Polski „racjonalnej”. Publicyści zarzucali mu jednak, że podziały kraju nijak mają się do jego hasła wyborczego, które przecież mówiło o zgodzie (Meller, 2015c, s. 37; Lis, 2015b, s. 2). Co do punktów programu wyborczego pojawiły się komentarze dotyczące in vitro. Mówiono, że w przeciwieństwie do A. Dudy B. Komorowski „nie zagląda ludziom do sypialni” (Kalukin, 2015b, s. 26) i nie zakazuje tej metody. Za jedyny błąd wskazano jedynie deklarację przeciw wydłużeniu wieku emerytalnego, a następnie podpisanie tej ustawy (Kalukin, 2015b,, s. 26).

W kwestiach wizerunkowych pisano o B. Komorowskim jako o kandydacie, który za wszelką cenę chce unikać kampanii negatywnej (Lis, 2015c, s. 2). Zdaniem publicystów B. Komorowski powinien umieć stanąć po stronie konstytucji „i powiedzieć otwartym tekstem, na czym polega neutralność religijna i gdzie są

11 Chodzi tu o zdjęcie B. Komorowskiego z Piotrem P., byłym oficerem Wojskowych Służb Informacyjnych, który potem był zamieszany również m.in. w aferę ze SKOK-ami. (Zob. szerzej: Molga, 2015). 
granice interwencji władzy religijnej w tworzeniu prawa" (Pawlicka, 2015c, s. 36). Podkreślano, że B. Komorowski w trakcie swojej kampanii „nie błyszczał, nie powiedział niczego, czego byśmy nie wiedzieli” (Lis, 2015e, s. 3). Wskazywano, że mimo to potwierdził swoją rzetelność, przewidywalność, solidność i odpowiedzialność, które - zdaniem T. Lisa - charakteryzowały jego prezydenturę (Lis, 2015e, s. 3).

Po pierwszej turze wyborów pisano, że B. Komorowski miał szanse, aby już po pierwszym głosowaniu zwyciężyć, ale sam uczynił to zwycięstwo niemożliwym (Lis, 2015d, s. 2). Określany był jako „samotna wyspa chroniąca majestat Rzeczypospolitej" pośród innych kandydatów (Kalukin, 2015e, s. 6 ). Zauważano, że popełnił masę błędów w kampanii, co nie powinno przekreślać jego atutów, jakimi miały być odpowiedzialność, przewidywalność i niezależność, czego zdaniem publicystów brakowało A. Dudzie (Lis, 2015a, s. 5). T. Lis uważał, że wprawdzie B. Komorowski ma wiele wad i deficytów, jednak „nie ma absolutnie nic wspólnego z postacią bezwzględnej PiS-owskiej propagandy" (Lis, 2015a, s. 5). Uważano, że B. Komorowski chciał Polakom dawać wolność, z kolei J. Kaczyński i A. Duda chcieli cenzurować ich myśli (Krzymowski, 2015c, s. 28). Dobrym podsumowaniem ogółu wypowiedzi publicystów na temat wizerunku B. Komorowskiego może być zdanie napisane przez Zbigniewa Hołdysa: „zły kandydat, dobry prezydent" (Hołdys, 2015, s. 54).

Podobnie jak w przypadku A. Dudy, niewiele pojawiło się komentarzy na temat wystąpień medialnych B. Komorowskiego. Twierdzono jedynie, że w debacie przed drugą turą wyborów wypadł znacznie lepiej od swojego kontrkandydata (Lis, 2015d, s. 2).

Przechodząc do kwestii relacji między kandydatami oraz relacji pomiędzy ich partiami (w przypadku B. Komorowskiego komentarze o spotkaniach z wyborcami także się nie pojawiły), również doszukano się odniesień do zależności kandydata od partii. Pisano, że B. Komorowski nie chciał być prezydentem partyjnym, płacić za błędy i porażki partii, i za takiego go, ich zdaniem, uznano (Lis, 2015c, s. 2). Pojawiły się opinie, że hasło B. Komorowskiego „Zgoda i bezpieczeństwo" dałoby znacznie lepszy efekt, gdyby prezydent od początku kampanii stanowczo zaznaczał kontrast pomiędzy sobą a swoim głównym oponentem i reagował na jego ataki. T. Lis w swoim „wstępniaku” tuż po pierwszej turze wyborów pisał, że politycy PiS od lat dorzucają B. Komorowskiemu kolejnych epitetów, takich jak: głupek, burak, zdrajca (Lis, 2015c, s. 2). Twierdzono jednak, że jeśli nic nieoczekiwanego nie wydarzy się przed drugą turą, B. Komorowski niewielką przewagą pokona A. Dudę (Kalukin, 2015e, s. 6). 


\section{PODSUMOWANIE I WNIOSKI}

Przedmiotem analizy badawczej były teksty publicystyczne tygodnika opinii „Newsweek”. Analizie poddano 8 wydań tytułu od 30 marca do 18 maja - ostatniego wydania tuż przed drugą turą głosowania. Analizie poddano 35 tekstów, w których poruszono tematykę kampanijną, pominięto te teksty, które kampanii dotyczyły, ale nie było w nich wzmianki o dwóch czołowych kandydatach. Tym samym w analizowanych wydaniach przebadano kolejno: 5, 3, 4, 4, 4, 4, 5 i 6 testów. Niemal w każdym numerze autorami tekstów byli ci sami publicyści ${ }^{12}$. Najwięcej analizowanych tekstów napisał redaktor naczelny - Tomasz Lis.

Warto zauważyć, że nieco więcej komentarzy poświęcono A. Dudzie. Były to jednak w większości komentarze negatywne. W przytaczanych cytatach i opisach pojawiały się określenia nieprzychylne, krytyczne, określenia nacechowane negatywnie, takie jak: „oszust”, „,cyniczny kandydat”, „kandydat kopiuj i wklej”, „rozmazany”, , plastikowy”, , pan nikt” etc. W przypadku B. Komorowskiego było ich nieco mniej. Uważano wprawdzie, że prowadzi „niemrawą kampanię” i „ma wiele wad i deficytów”, jednak wizerunek ówczesnego prezydenta był niekiedy przez publicystów chwalony. Używano określeń, które kontrastowały z tym, co pisano o kandydacie PiS-u (np., że B. Komorowski „nie zagląda ludziom do sypialni” - w kontekście zapłodnienia in vitro). Używano sformułowań implikujących wygraną w wyborach i przewagę nad kontrkandydatem: „skazany na władzę”, jego kampania to „oaza kultury politycznej” oraz, że wprawdzie jest „złym kandydatem”, jednak „dobrym prezydentem”.

W kontekście postawionych pytań badawczych można stwierdzić, że dochodzi do stronniczości mediów. Sugerując się typologią stronniczości wyodrębnioną przez Denisa McQuaila ${ }^{13}$ (1992, s. 191-194), można wnioskować, że jest to stronniczość niewątpliwa, czyli jawna i zamierzona. W badanych tekstach publicystycznych widać było faworyzowanie B. Komorowskiego i silną krytykę A. Dudy. Co za tym idzie, na tej podstawie można wysnuć wniosek, że opinie te nie były do końca obiektywne i wskazywały na subiektywną ocenę publicystów. Warto zauważyć, że nie wszystkie informacje i wydarzenia towarzyszące kampanii pojawiły się w analizowanych tekstach. Może to wynikać ze specyfiki

12 Tomasz Lis, Marcin Meller, Zbigniew Hołdys, Rafał Kalukin, Michał Krzymowski, Aleksandra Pawlicka.

13 D. McQuail wyróżnia cztery typy stronniczości: niewątpliwą (czyli jawną i zamierzoną), propagandową (czyli ukrytą i zamierzoną), mimowolną (czyli jawną i niezamierzoną) oraz ideologiczną (czyli ukrytą i niezamierzoną), (McQuail, 1992, s. 193-195). 
gatunkowej badanych treści oraz częstotliwości ukazywania się analizowanego materiału. Nie można jednak zakładać, że są to jedyne powody, kiedy przed chwilą wnioskowano o stronniczości, faworyzowaniu i subiektywizmie.

\section{BIBLIOGRAFIA:}

Bartmiński, J., Tokarski R. (1986). Językowy obraz świata a spójność tekstu. W: T. Dobrzyńska, E. Janus (red.). Teoria tekstu. Wrocław.

Cichosz, M. (2004). Wizerunek politycznego lidera. W: M. Jeziński (red.). Marketing polityczny. W poszukiwaniu strategii wyborczego sukcesu. Toruń: Wydawnictwo Adam Marszałek.

Cwalina, W. (2000). Telewizyjna reklama polityczna. Lublin: Towarzystwo Naukowe KUL.

Fleischer, M. (2005). Media w perspektywie konstruktywizmu. Kultura i Komunikacja, $1-2,10-33$.

Fleischer, M. (2000). Ujęcie z punktu widzenia teorii systemów i konstruktywizmu.

W: A. Dąbrowska, J. Anusiewicz (red.). Język a kultura, t. 13. Wrocław: Wydawnictwo Uniwersytetu Wrocławskiego.

Grzegorczykowa, R. (1990). Wprowadzenie do semantyki językoznawczej. Warszawa: Wydawnictwo Naukowe PWN.

Hołdys, Z. (2015). Pamięć rybki. Newsweek, 21, 54.

Instytut Monitorowania Mediów (2015). Pobrane z: https://www.imm.com.pl/immnajbardziej-opiniotworcze-media-w-2015-roku-glownym-tematem-wyboryprezydenckie-i-parlamentarne-oraz-rzeczywistosc-powyborcza/.

Jeziński, M. (2005). Wizerunek polityczny jako element strategii wyborczej. W: B. Dobek-Ostrowska (red.). Kampania wyborcza: marketingowe aspekty komunikowania politycznego. Wrocław: Wydawnictwo Uniwersytetu Wrocławskiego.

Kalukin, R. (2015a). Cyrk polityczny. Newsweek, 14, 18-20.

Kalukin, R. (2015b). Pan nikt i wkurzeni. Newsweek, 17, 26-28.

Kalukin, R. (2015c). Wszyscy ludzie prezydenta?. Newsweek, 16, 40-43.

Kalukin, R. (2015d). Ten w skórze jest nasz!. Newsweek, 21, 32-34.

Kalukin, R. (2015e). Co zrobić z tą wygraną. Newsweek, 20, 6-10.

Kasińska-Metryka A. (2006). Wizerunek kandydata na prezydenta - polityczna poprawność kontra marketingowe wyzwania. Athenaeum Political Science, 14-15, 157-168.

Kępa-Figura, D., Nowak, P. (2006). Językowy obraz świata a medialny obraz świata. Zeszyty Prasoznawcze, 1-2, 51-62.

Kolczyński, M. (2008). Strategie komunikowania politycznego. Katowice: Wydawnictwo Uniwersytetu Śląskiego.

Krzymowski, M. (2015a). Połowa Hofmana. Newsweek, 18, 30-33.

Krzymowski, M. (2015b). Gilotyna prezesa. Newsweek, 19, 20-22.

Krzymowski, M. (2015c). Rzuty karne. Newsweek, 21, 26-31.

Lippmann, W. Public Opinion. Pobrane z: https://wwnorton.com/college/history/america-essential-learning/docs/WLippmann-Public_Opinion-1922.pdf. 
Lis, T. (2015a). Najprostszy wybór w życiu. Newsweek, 21, 4-5.

Lis, T. (2015b). Kandydat na posyłki. Newsweek, 14, 2.

Lis, T. (2015c). Koty popełniają seppuku. Newsweek, 15, 2.

Lis, T. (2015d). Finał ligi bez mistrzów. Newsweek, 20, 2-3.

Lis, T. (2015e). Ta następna niedziela. Newsweek, 19, 2-3.

Maguś, W. (2014). Wizerunki polityków w cieniu zdarzeń nadzwyczajnych. Kampania wyborcza na urząd Prezydenta Rzeczypospolitej Polskiej w 2010 roku, Lublin: Wydawnictwo UMCS.

McQuail, D. (1992). Media Performance: Mass Communication and the Public Interest. London-Newbury Park: Sage Publications.

Michalski, C. (2015). Eurostraszak Dudy. Newsweek, 14, 22-25.

Meller, M. (2015a). Święta felietonowej grozy. Newsweek, 14, 44.

Meller, M. (2015b). Pomidor. Newsweek, 20, 20.

Meller, M. (2015c). Moja Polska radykalna. Newsweek, 15, 37.

Molga, T. (2015). Człowiek ze zdjęcia. Kariera Piotra P., którego przypadkowy uścisk ręki ma rozłożyć kampanię Bronisława Komorowskiego. Pobrane z: https://natemat. pl/137621,czlowiek-ze-zdjecia-kariera-piotra-p-ktorego-przypadkowy-uscisk-rekima-rozlozyc-kampanie-bronislawa-komorowskiego.

Ogonowska, A. (2003). Edukacja medialna. Klucz do rozumienia społecznej rzeczywistości. Kraków: Wydawnictwo Towarzystwa Naukowego „Societas Vistulana”.

Państwowa Komisja Wyborcza (2015). Pobrane z: https://prezydent2015.pkw.gov.pl/ komitety/17_Komitet_Wyborczy_Kandydata_na_Prezydenta_Rzeczypospolitej_Polskiej_Andrzeja_Dudy.

Państwowa Komisja Wyborcza (2015). Pobrane z: https://prezydent2015.pkw.gov.pl/ kalendarz_wyborczy.

Państwowa Komisja Wyborcza (2015). Pobrane z: https://prezydent2015.pkw.gov. pl/306_Kandydaci.

Państwowa Komisja Wyborcza (2015). Pobrane z: https://prezydent2015.pkw.gov.pl/ kalendarz_wyborczy.

Pawlicka, A. (2015a). Politycy i wentyle. Newsweek, 20, 17-19.

Pawlicka, A. (2015b). Pan nikt i ręka w nocniku. Newsweek, 21, 21-25.

Pawlicka, A. (2015c). Partie robią z Polaków idiotów. Newsweek, 16, 34-37.

Pluzińska, E. (2015). Pobrane z: https://www.infor.pl/prawo/wybory/wybory-prezydenckie-2015/694602,Wybory-prezydenckie-2015-jak-zostac-prezydentem-w-RP. html.

Ptaszek, G. (2015). Jak badać medialny obraz świata? W: I. Hofman, D. Kępa-Figura (red.). Współczesne media. Medialny obraz świata. Zagadnienia teoretyczne. Lublin: Wydawnictwo UMCS.

Reeves, B., Nass C. (2000). Media i ludzie, tłum. H. Szczerkowska. Warszawa: Państwowy Instytut Wydawniczy.

Stephan, W. G., Stephan C. W. (2003). Wywieranie wpływu przez grupy. Psychologia relacji. Gdańsk: Gdańskie Wydawnictwo Psychologiczne. 
Szalkiewicz, W. K. (2008). Kandydat. Jak wygrać wybory, Bydgoszcz: Oficyna Wydawnicza Branta.

Szmyd, J. (2012). Medialny obraz rzeczywistości jako główna orientacja poznawcza i praktyczna $w$ świecie. W: K. Pokorna-Ignatowicz (red.). Medialny obraz rodziny i płci, Kraków: Oficyna Wydawnicza AFM.

Wybory prezydenckie Rzeczypospolitej Polskiej 2015. Pierwsze głosowanie (2015). Pobrane z: https://prezydent2015.pkw.gov.pl/319_Pierwsze_glosowanie.

Zaręba, A. (2011). Wizerunek polityka w III RP: kreacja instrumentarium, kompetencje komunikacyjne. Rzeszów: Wydawnictwo Uniwersytetu Rzeszowskiego. 